Check for updates

New York

Cite this as: BMJ 2021;374:n2030 http://dx.doi.org/10.1136/bmj.n2030 Published: 16 August 2021

\section{Covid-19: Cases in children rise sharply in US as doctors call for vaccine approval}

\author{
Janice Hopkins Tanne
}

Children too young to be vaccinated are increasingly becoming infected with SARS-CoV-2 in the US, just as schools begin to reopen for in-person classes.

The American Academy of Pediatrics, which represents 67000 primary care and specialist paediatricians, urged the Food and Drug Administration to work "aggressively toward authorising safe and effective covid-19 vaccines for children under age 12 as soon as possible.” During July 12 ooo new infections were recorded in children, increasing to 94000 by the first week of August, said the academy. ${ }^{12}$

As of 14 August a record 1902 children were admitted to hospital with covid-19. ${ }^{3}$ The US has nearly 74 million children under 18.

Anthony Fauci, director of the National Institute of Allergy and Infectious Diseases, said at a White House briefing, "The delta variant is much more highly transmissible than was alpha. So, given that, you will see more children likely to get infected ... a certain percentage of them will require hospitalisation." 4

The academy and the Children's Hospital Association said that the week ending 29 July "saw the largest week-over-week percentage increase in paediatric covid-19 cases since the start of the epidemic." ${ }^{1}$

The academy said in its letter to the FDA, "Since the pandemic began, children have represented 14.3\% of total cumulated cases. However, for the week ending July 29, children were $19.0 \%$ of reported weekly cases. The higher proportion of cases in this age group could be contributing to the spread of covid-19. Sadly, over 350 children have died.” It added that millions had missed schooling, facing social isolation and too often the death of parents and caregivers.

The rise in covid-19 cases in children is complicated by an increase in cases of respiratory syncytial virus that is usually seen in winter.

Only the Pfizer-BioNTech vaccine is approved for use in children aged 12 to 17 . Both Pfizer and Moderna are conducting clinical trials of their vaccines in children aged 5 to 11, and Pfizer is also studying its vaccine in children under 5 .

The academy urged the FDA to approve the vaccines on the basis of data from the initial trial cohort and to rely on two month follow-up safety data as used for adult vaccines rather than its planned six month follow-up data. It said, "Based on evidence from the over 340 million doses [of covid-19 vaccines] administered to adults and to adolescents aged 12-17 as well as among adults 18 and older, there is no biological plausibility for serious adverse immunological and inflammatory events to occur more than two months after covid-19 vaccine administration.”

The academy also asked the FDA to evaluate clinical trial requirements for children under 5 .

Peter Hotez, dean of the National School of Tropical Medicine at Baylor College of Medicine in Houston, Texas, told CNN, “It's starting to look really ominous in the south. If you look at rates of transmission in Florida and Louisiana, they're probably the highest in the world ... There is a screaming level of transmission across the southern states right now.

And now we're starting to see this happening among younger age groups." 5

Cases of covid-19 among children are rising in southern states such as Florida, Alabama, Louisiana, Mississippi, Arkansas, and Texas. Adult vaccination rates are low in these states, and the delta variant is causing nearly all new cases. Fauci called it "an epidemic of the unvaccinated."

Children's hospitals throughout the south reported that many children had been infected by an unvaccinated adult in their household, and several hospitals said that they had been at bed capacity for weeks. ${ }^{6}$ The Dallas-Fort Worth area, which has about 300 paediatric intensive care beds, was reported to be out of such beds for children. ${ }^{7}$

The Centers for Disease Control and Prevention recommended that schools require masks for students, staff, teachers, and visitors, "regardless of vaccination status," and that "students, parents, teachers, and staff get vaccinated as soon as possible" to stop the spread of the virus to children who are not yet eligible for vaccination. ${ }^{8}$

However, Ron DeSantis, governor of Florida, and Greg Abbott, governor of Texas, have both forbidden local authorities from making masks mandatory. Some cities and school districts have nevertheless required masks, and the dispute has bounced back and forth in the courts. Abbott has hired health workers from out of state to help hospitals cope with the surge and has asked hospitals to postpone elective procedures. ${ }^{7}$

John Vanchiere, paediatric infectious disease specialist at University Health in Shreveport, Louisiana, said at a press conference, "This is not a time for politics, for fighting or threatening lawsuits about masks. Masks save lives." 6

\section{UK picture}

The increase in child admissions with covid-19 does not seem to be replicated in the UK. Jane Bayreuther, paediatric clinical lead at the University Hospital

\section{Southern states "look ominous"}


Southampton NHS Foundation Trust and chair of the Association of Paediatric Emergency Medicine, commented, "We are not seeing children sick from covid at our local paediatric intensive care unit, and my understanding is that the national picture is similar.

"However, we are seeing sick children from other respiratory conditions in our emergency departments nationally. Some of them have positive covid swabs, but that's not usually the reason they are ill. We are not seeing the high rates of covid illnesses suggested by US data."

1 Letter from Lee Savio Beers, president of the American Academy of Pediatrics, to Janet Woodcock acting commissioner, Food and Drug Administration. 5 Aug 2021. https://downloads.aap.org/DOFA/AAP\%20Letter\%20to\%20FDA\%20on\%20Timeline\%20for\%20Authorization\%20of\%20COVID19\%20Vaccine\%20for\%20Children_08_05_21.pdf

2 American Academy of Pediatrics. Children and covid-19: state-level data report. 5 Aug 2021. https://www.aap.org/en/pages/2019-novel-coronavirus-covid-19-infections/children-and-covid19-state-level-data-report/

3 Borter G. Children hospitalized with covid-19 in US hits record number. Reuters. 14 Aug 2021. https://www.reuters.com/world/us/children-hospitalized-with-covid-19-us-hits-record-number2021-08-14/

4 Press briefing by White House covid-19 response team and public health officials. 12 Aug 2021 https://whitehouse.gov/briefing-room/press-briefings/2021/08/12/press-briefing-by-white-housecovid-19-response-team-and-public-health-officials/

5 Elamroussi A. "This is starting to look really ominous in the South": covid-19 surge continues in the US. CNN. 14 Aug 2021. https://edition.cnn.com/2021/08/14/health/us-coronavirus-Saturday

6 McCausland P. Kids sick with covid are filling up children's hospitals in areas seeing spikes. NBC News. 9 Aug 2021. https://www.nbcnews.com/news/us-news/kids-sick-covid-are-filling-childrens-hospitals-areas-seeing-n1276238

7 Steele T. Dallas-Fort Worth out of ICU beds for children as surge in covid-19 cases continues, group says. Dallas News 2021 Aug 12. https://www.dallasnews.com/news/publichealth/2021/08/12/dallas-fort-worth-out-of-icu-beds-for-children-as-surge-in-covid-19-casescontinues-group-says/

8 Centers for Disease Control and Prevention. Put on your masks and thinking caps: covid data tracker weekly review. 13 Aug 2021. https://www.cdc.gov/coronavirus/2019-ncov/covid-data/covidview/index.html

This article is made freely available for use in accordance with BMJ's website terms and conditions for the duration of the covid-19 pandemic or until otherwise determined by BMJ. You may use, download and print the article for any lawful, non-commercial purpose (including text and data mining) provided that all copyright notices and trade marks are retained. 